Proc. Estonian Acad. Sci. Geol., 2002, 51, 1, 5-15

\title{
Thermal conductivity of Cambrian siliciclastic rocks from the Baltic basin
}

\author{
Argo Jõeleht ${ }^{\mathrm{a}}$, Kalle Kirsimäe ${ }^{\mathrm{a}}$, Alla Shogenova ${ }^{\mathrm{b}}$, Saulius Šliaupa $^{\mathrm{c}}$, \\ Ilmo T. Kukkonen ${ }^{\mathrm{d}}$, Vita Rastenienéc, and Angelīna Zabele ${ }^{\mathrm{e}}$ \\ a Institute of Geology, University of Tartu, Vanemuise 46, 51014 Tartu, Estonia; ajoeleht@ut.ee, \\ arps@ut.ee \\ b Institute of Geology, Tallinn Technical University, Estonia pst. 7, 10143 Tallinn, Estonia; alla@ gi.ee \\ c Institute of Geology, T. Ševčenkos 13, LT 2600 Vilnius, Lithuania; sliaupa@geologin.lt, \\ vitarast@geologin.lt \\ d Geological Survey of Finland, P.O. Box 96, FIN-02151 Espoo, Finland; ilmo.kukkonen@ gsf.fi \\ e University of Latvia, Alberta St.10, Riga LV-1010, Latvia; azabele@lanet.lv
}

Received 6 February 2001, in revised form 13 September 2001

\begin{abstract}
The thermal conductivity of Cambrian siliciclastic rocks, mainly sandstones and siltstones, was studied together with their chemical composition and other petrophysical properties in Estonia, Latvia, and Lithuania. The thermal conductivity is mainly controlled by porosity and rock composition. It was found that the Wiener and layered mixing and geometric mean models approximated best the thermal conductivity vs. porosity relationship of quartz-rich rocks within the measured porosity range $(0-30 \%)$. The matrix thermal conductivity is positively correlated only with the silica content which reflects the content of quartz, whereas other rock-forming minerals decrease the matrix thermal conductivity. The thermal conductivity of siliciclastic rocks correlates well with porosity-dependent parameters (wet density, apparent resistivity, elastic properties), but has no relation to magnetic properties.
\end{abstract}

Key words: thermal conductivity, petrophysical properties, siliciclastic rocks, Cambrian, Baltic basin.

\section{INTRODUCTION}

The thermal conductivity of rocks is a key parameter in geothermal investigations. It is important in heat flow density studies and in exploitation of geothermal resources, but also in basin modelling. The thermal conductivity of minerals is relatively well studied (e.g., see compilations in Čermák \& Rybach 1982; Clauser \& Huenges 1995; Schön 1996). Although the thermal conductivity in monomineralic systems is mainly controlled by porosity and the thermal conductivity of pore fluid, the exact mathematical function between these two parameters is not self-evident due to variations in pore structure, microfracturing, 
and degree of saturation. A number of petrophysical parameters including thermal conductivity, and the chemical composition of rocks were measured during the investigation of reservoir properties of the Cambrian rocks of the Baltic basin. The aim of this paper is to study the effect of the composition and porosity on the thermal conductivity of the Cambrian siliciclastic rocks of the Baltic basin using the above-mentioned database. The porosity of these rocks varies in a wide range, which allows correlation of their thermal conductivity with other petrophysical properties.

\section{MATERIAL AND METHODS}

\section{Geological setting}

Cambrian deposits represent the basal part of the sedimentary sequence of the Baltic basin, ranging in thickness from a few dozens of metres in the east and northeast to more than $500 \mathrm{~m}$ in the western part of the Baltic Sea. The Cambrian siliciclastic rocks crop out in northern Estonia, while the burial depth increases gradually to more than $2 \mathrm{~km}$ in southwestern Lithuania. Samples of Cambrian rocks were obtained from 31 Lithuanian, Latvian, and Estonian drill cores (Fig. 1), from the parts that were cemented strongly enough to cut with a saw. Lithologically the samples mostly represent sandstones and siltstones composed of quartz.

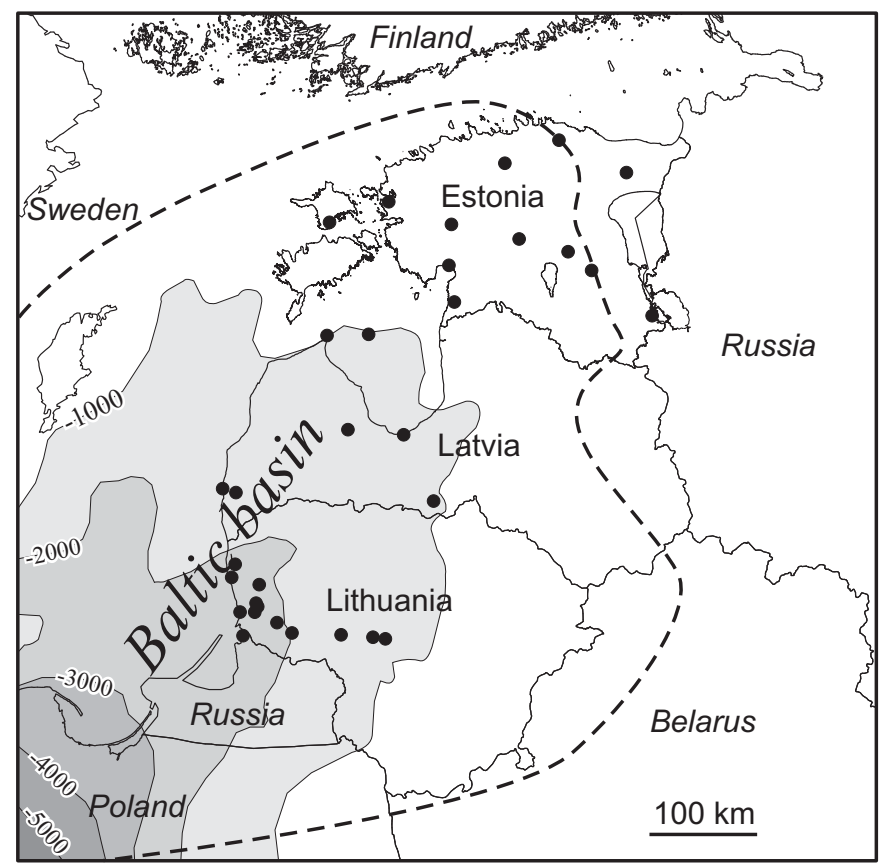

Fig. 1. Location of sampled boreholes. The border of the Baltic basin (dashed line) is drawn after Mokrik (1997). 


\section{Measurements}

The thermal conductivity was measured at room temperature on 251 watersaturated samples at the Geological Survey of Finland using a divided bar instrument (Järvimäki 1968). Relative errors of the equipment are 2-4\% (Kukkonen \& Peltoniemi 1998). Disks of about $24 \mathrm{~mm} \times 24 \mathrm{~mm} \times 8 \mathrm{~mm}$ were prepared from cubic samples used for measurements of other petrophysical properties. Most of the samples were horizontally oriented (parallel to bedding) and thus the measured thermal conductivity represents mostly the vertical (along the core axis) component of conductivity.

Measurements of other petrophysical properties along with thermal conductivity and elastic wave velocities were performed on cubes with $24 \mathrm{~mm}$ sides. Magnetic susceptibility, saturation isothermal remanent magnetization, natural remanent magnetization, electrical resistivity, dielectric constant, wet P-wave velocity, effective porosity, and wet, dry and grain densities were measured in the Petrophysical Laboratory of Research Institute of Earth Crust of St. Petersburg University using the methods described in Prijatkin \& Poljakov (1983) and Shogenova \& Puura (1997).

Dry $\mathrm{P}$-wave and $\mathrm{S}$-wave velocities $\left(V_{\mathrm{P}}\right.$ and $\left.V_{\mathrm{S}}\right)$ were measured at the GeoForschungsZentrum Potsdam. Measurements of the air-dry samples were made in two directions using shearwave transducers. The digital signals that contained both P-wave and S-wave arrivals were stored for later processing. For better recognition of $S$-wave arrivals, measurements in each direction included also a second measurement with one transducer turned $180^{\circ}$, allowing saving a transverse signal with opposite sign. During data processing, these two signals were subtracted from each other, which resulted in minimizing the P-wave signal and amplifying the $S$-wave signal. The reported elastic wave velocities are averages of measurements in two directions.

The same samples were used for all measurements, which improves the correlation of measurement results. The bulk chemical composition of rocks was determined by X-ray fluorescence analysis in the All-Russian Geological Institute, St. Petersburg.

\section{Thermal conductivity-porosity models}

Several models have been discussed in the literature to describe the relationship between thermal conductivity and porosity, assuming thermal conductivities of different mineral phases and fluids. The most common models are the arithmetic, harmonic, and geometric means. In addition, the dispersive or Maxwell model was introduced by Beck (1976):

$$
\lambda_{\mathrm{d}}=\lambda_{\mathrm{m}}\left[\frac{(2 r+1)-2 \phi(r-1)}{(2 r+1)+\phi(r-1)}\right],
$$


where $r$ is the conductivity ratio $\lambda_{\mathrm{m}} / \lambda_{\mathrm{f}}$ of a two-component system (unitless), $\lambda_{\mathrm{m}}$ and $\lambda_{\mathrm{f}}$ are the thermal conductivity $\left(\mathrm{W} \mathrm{m}^{-1} \mathrm{~K}^{-1}\right)$ of the matrix and fluid, respectively, and $\phi$ is the porosity (unitless).

Buntebarth \& Schopper (1997) showed that mathematical modification of the Wiener mixing model

$$
\begin{aligned}
\frac{\lambda_{\mathrm{tot}}}{\lambda_{\mathrm{m}}} & =\frac{1-\xi \phi}{1+\alpha \xi \phi}, \\
\xi & =\frac{1-\zeta}{1+\alpha \zeta}, \\
\zeta & =\frac{\lambda_{\mathrm{f}}}{\lambda_{\mathrm{m}}}
\end{aligned}
$$

covers all previously mentioned models (except the geometric mean model) if the parameter $\alpha$ is properly selected. For example, the cases $\alpha=0$ and $\alpha>80$ correspond respectively to arithmetic and harmonic mean models, which are the upper and lower thermal conductivity limits of the layered media. The parameter $\alpha$ is assumed to describe the geometry of the liquid phase in pores and varies with wetting properties of the liquid. Thus, $\alpha=0$ represents a case where pore fluid has perfect wetting conditions, pores are completely filled, and thermal contact resistance within the rock is minimal, whereas the case $\alpha>80$ corresponds to the opposite conditions.

The arithmetic and harmonic mean models correspond to parallel and perpendicular components and thus, as mentioned above, to upper $\lambda_{\mathrm{U}}$ and lower $\lambda_{\mathrm{L}}$ thermal conductivity limits of the layered media. It has also been suggested to use the geometric mean $\lambda_{\mathrm{U} * \mathrm{~L}}$ of these parameters to describe a mixture of equal amounts of randomly distributed parallel and series arrangements in a layered medium (Beck \& Beck 1965; Pribnow \& Sass 1995):

$$
\lambda_{\mathrm{U} * \mathrm{~L}}=\lambda_{\mathrm{U}}^{0.5} \lambda_{\mathrm{L}}^{0.5}
$$

\section{RESULTS}

Most of the samples have a relatively high thermal conductivity in the range 2.3-6.7 W m $\mathrm{W}^{-1} \mathrm{~K}^{-1}$ with a mean value of $4.3 \mathrm{~W} \mathrm{~m}^{-1} \mathrm{~K}^{-1}$. This can be attributed to the high content of quartz in rocks.

In our study, the thermal conductivity increases with the burial depth because of the compaction-related reduction of porosity. In general, the porosity decreases from $30 \pm 5 \%$ at 0 burial depth in Estonia to $10 \pm 5 \%$ at $2400 \mathrm{~m}$ depth in western Lithuania (Fig. 2). Consequently, the average thermal conductivity increases from $3.3 \pm 0.7 \mathrm{~W} \mathrm{~m}^{-1} \mathrm{~K}^{-1}$ in Estonia and $3.8 \pm 0.7 \mathrm{~W} \mathrm{~m}^{-1} \mathrm{~K}^{-1}$ in Latvia and central Lithuania to $5.1 \pm 1.1 \mathrm{~W} \mathrm{~m}^{-1} \mathrm{~K}^{-1}$ in western Lithuania. 
Fig. 2. The increase in the thermal conductivity with the increase in depth (a) can be explained with compaction-related decrease in porosity (b). The data are divided into two groups according to the $\mathrm{SiO}_{2}$ content (black dots $\mathrm{SiO}_{2}>90 \%$, open squares $\mathrm{SiO}_{2}<90 \%$ ). The value $90 \%$ corresponds to about the average content of $\mathrm{SiO}_{2}$.
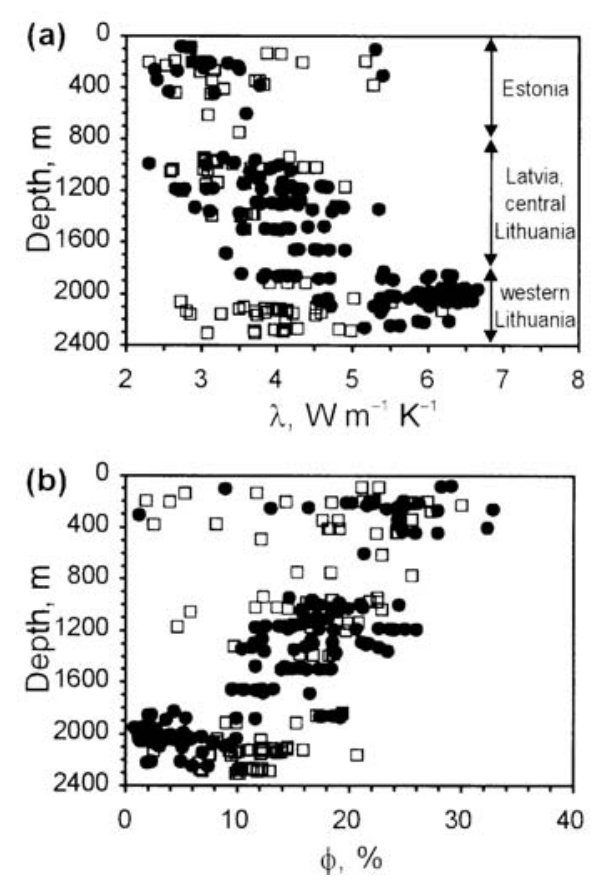

Two exceptional sample groups occur in the general porosity-depth trend. The first group is represented by the samples from the shallower part of the basin in Estonia where porosity is sometimes significantly decreased by dolomitization (in Fig. 2 shown by low porosity values of rocks with less than the average $\mathrm{SiO}_{2}$ content).

At depths greater than $1800 \mathrm{~m}$ in western Lithuania the samples with the silica content above average have lower porosity and higher thermal conductivity (Fig. 2). This second group is represented by the samples from the high heat flow density $\left(80-90 \mathrm{~mW} \mathrm{~m}^{-2}\right.$ ) area where temperatures exceeding $80^{\circ} \mathrm{C}$ have caused extensive secondary quartz cementation, which has drastically reduced the porosity to less than $5 \%$. For this reason, the thermal conductivity of clastic rocks is highest in western Lithuania.

As could be expected from the strong correlation between the thermal conductivity and porosity, a good correlation occurred between the thermal conductivity and porosity-dependent parameters, such as wet density, elastic wave velocities, and apparent electric resistivity (Fig. 3). Also, as anticipated, the thermal conductivity is related neither to magnetic properties (magnetic susceptibility, saturation isothermal remanent magnetization, natural remanent magnetization) nor to the dielectric constant. The thermal conductivity of siliciclastic rocks depends only weakly on grain density because the latter rather reflects changes in rock composition. 

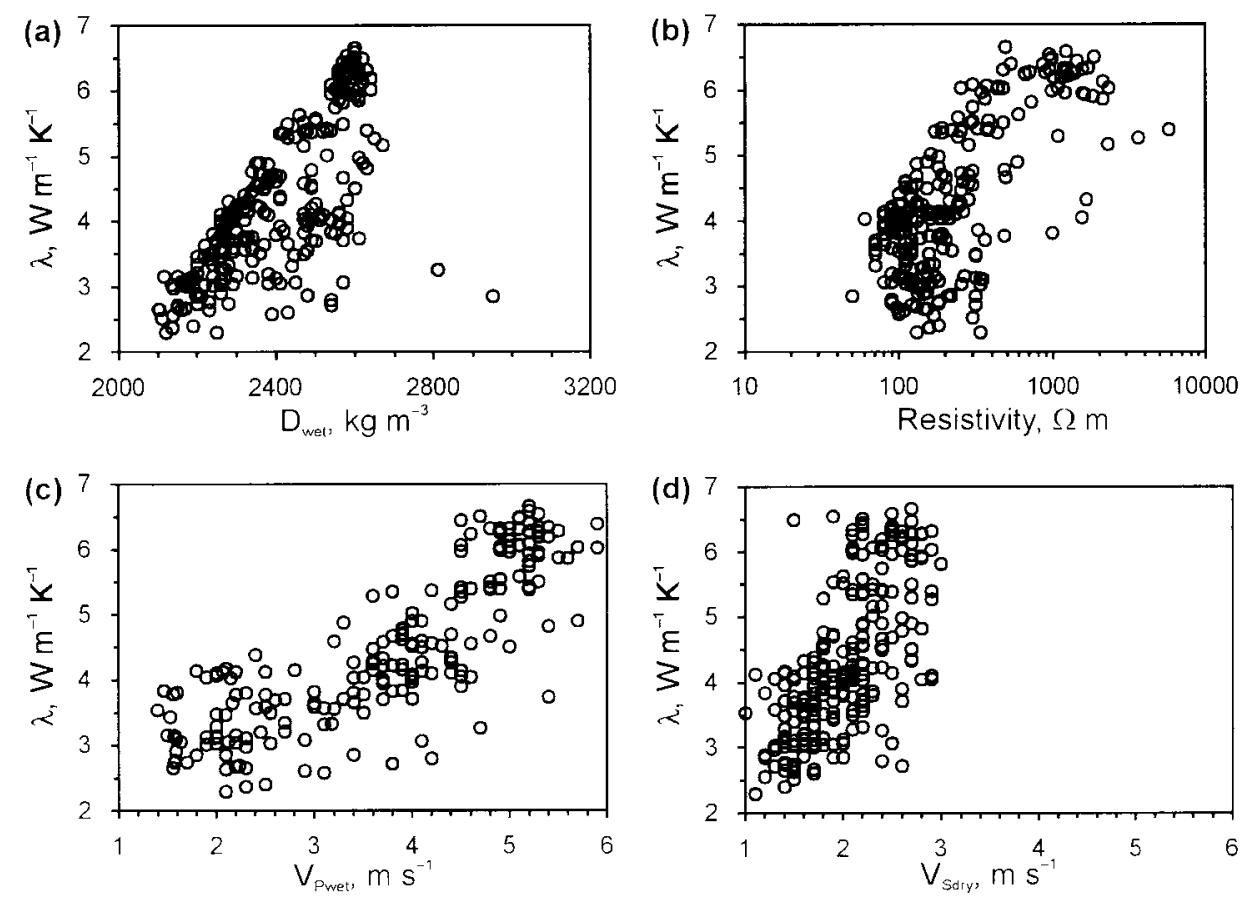

Fig. 3. Thermal conductivity versus porosity-dependent parameters such as (a) wet density, (b) apparent resistivity, and (c) elastic P-wave velocity in wet samples ( $\left.V_{\text {Pwet }}\right)$ and (d) S-wave velocity measured in dry samples $\left(V_{\text {Sdry }}\right)$.

\section{DISCUSSION}

The thermal conductivity is strongly controlled both by the porosity and the mineral composition of rocks. In order to separate these effects we first investigate monomineralic samples to find the best mathematical function to describe the thermal conductivity-porosity relationship. Secondly, using this function, we erase the effect of porosity by calculating the matrix thermal conductivity and study how the chemical composition affects it.

\section{Thermal conductivity-porosity models}

We checked the relationships between the thermal conductivity and porosity on selected samples in which the $\mathrm{SiO}_{2}$ content exceeds $95 \%$ (i.e. rocks are dominated by quartz). Thus the system can be treated as a two-component (quartz and water) system.

For the studied range of porosities and a suggested thermal conductivity of quartz, neither the arithmetic, Maxwell, nor the harmonic model can satisfactorily explain the observed thermal conductivity-porosity relationship in our data set 


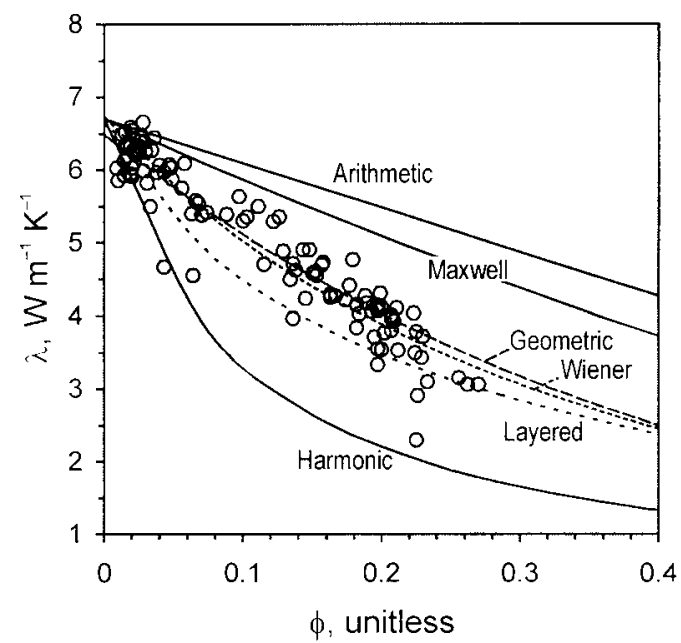

Fig. 4. Comparison of the thermal conductivity-porosity models on quartz dominated samples $\left(\mathrm{SiO}_{2}\right.$ content is more than 95\%). The arithmetic, Maxwell, and geometric mean models tend to overestimate and the harmonic mean model tends to underestimate the thermal conductivity. Approximately equally good fits to the data were achieved with the Wiener (Eqs. (2)-(4)), layered (Eq. (5)), and geometric mean models.

(Fig. 4) because the slopes of theoretical lines do not correspond to the trend in the data. However, the Wiener model (Eqs. (2)-(4)), the layered model $\left(\lambda_{\mathrm{U}^{*} \mathrm{~L}}\right.$; Eq. (5)), and the geometric mean model give approximately equally good fits to the data. For the Wiener model the best fit was obtained with a matrix thermal conductivity $\lambda_{\mathrm{m}}=6.7 \mathrm{~W} \mathrm{~m}^{-1} \mathrm{~K}^{-1}$ and $\alpha=3.6$. The fitted value 3.6 is smaller than the value 5 proposed by Buntebarth \& Schopper (1997). The layered model suggests a somewhat higher matrix thermal conductivity $\left(\lambda_{\mathrm{m}}=7.1 \mathrm{~W} \mathrm{~m}^{-1} \mathrm{~K}^{-1}\right)$ compared to the Wiener mixing model. Similarly to Pribnow \& Sass (1995), our data suggest that the geometric mean model slightly better approximates $\lambda_{\text {bulk }}$ than the layered model. The geometric mean model suggests the lowest matrix thermal conductivity $\left(\lambda_{\mathrm{m}}=6.5 \mathrm{~W} \mathrm{~m}^{-1} \mathrm{~K}^{-1}\right)$.

\section{The effect of the mineral composition}

The effect of porosity can be removed by calculating the matrix thermal conductivity using the mixing models. The following matrix thermal conductivity estimates are based on the Wiener mixing model (Eqs. (2)-(4)) and do not differ essentially from the estimates based on the layered model (Eq. (5)) or the geometric mean model.

As shown in Fig. 5, the thermal conductivity decreases as the relative amount of phyllosilicates (micas and clay minerals), carbonates, and feldspars (reflected by the contents of $\mathrm{Al}_{2} \mathrm{O}_{3}, \mathrm{CaO}+\mathrm{MgO}$, and $\mathrm{K}_{2} \mathrm{O}$, respectively) increases. This is expected because the thermal conductivity of these components is lower than that 

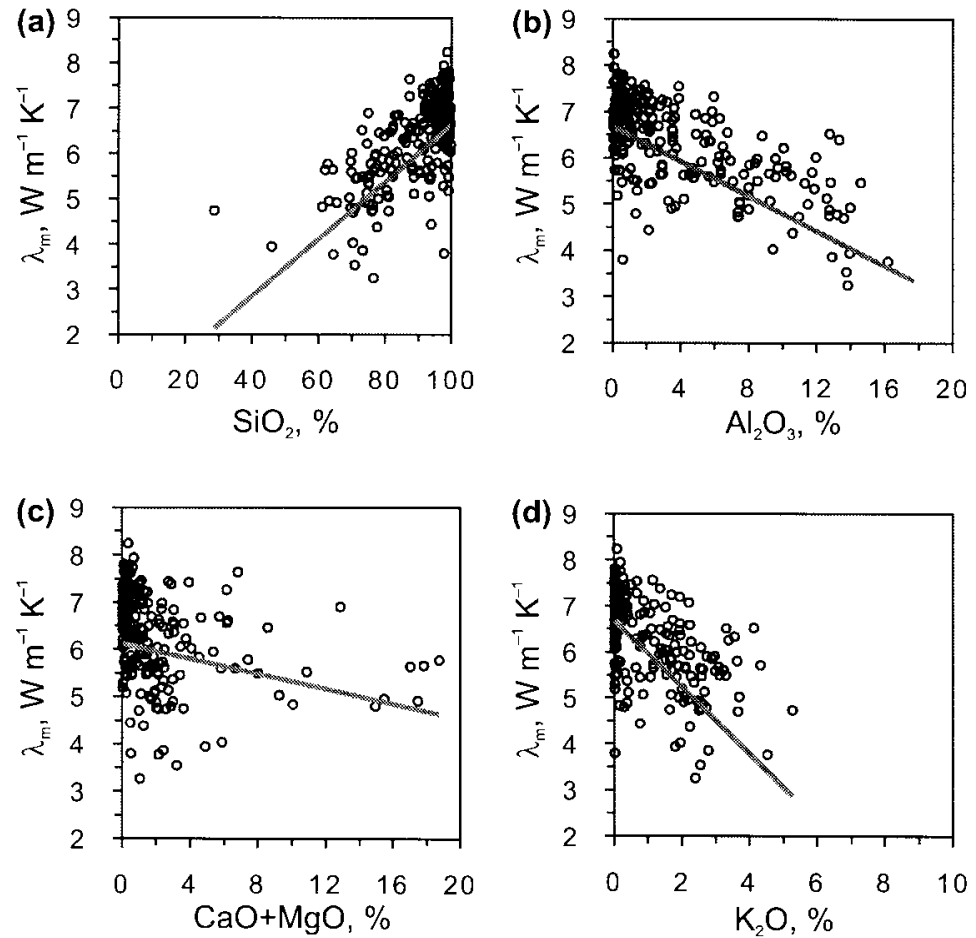

Fig. 5. The highest matrix thermal conductivity $\lambda_{\mathrm{m}}$ is related to quartz, which is reflected by the content of $\mathrm{SiO}_{2}$ (a). Other rock-forming minerals such as sheet silicates, carbonates, and K-feldspar, reflected by the contents of $\mathrm{Al}_{2} \mathrm{O}_{3}(\mathrm{~b}), \mathrm{CaO}+\mathrm{MgO}(\mathrm{c})$, and $\mathrm{K}_{2} \mathrm{O}$ (d), respectively, decrease the matrix thermal conductivity as their contents increase.

of quartz (7.7 $\mathrm{W} \mathrm{m}^{-1} \mathrm{~K}^{-1}$, Horai $1971 ; 6.9 \mathrm{~W} \mathrm{~m}^{-1} \mathrm{~K}^{-1}$ in this work). Dolomite, calcite, and K-feldspars have a thermal conductivity of $4.8-5.5 \mathrm{~W} \mathrm{~m}^{-1} \mathrm{~K}^{-1}$ (Horai 1971; Dreyer 1974; Diment \& Pratt 1988; Brigaud \& Vasseur 1989), 3.3-3.6 $\mathrm{W} \mathrm{m}^{-1} \mathrm{~K}^{-1}$ (Horai 1971; Brigaud \& Vasseur 1989), and 2.4-2.6 $\mathrm{W} \mathrm{m}^{-1} \mathrm{~K}^{-1}$ (Horai 1971), respectively. Although phyllosilicates are anisotropic and have a rather high thermal conductivity along structural layers, the average (smectite $1.9 \mathrm{~W} \mathrm{~m}^{-1} \mathrm{~K}^{-1}$, muscovite/illite - 1.9-2.5 $\mathrm{W} \mathrm{m}^{-1} \mathrm{~K}^{-1}$, chlorite - 3.3-6.2 $\mathrm{W} \mathrm{m}^{-1} \mathrm{~K}^{-1}$; Horai 1971; Brigaud \& Vasseur 1989) is lower than that of quartz. Moreover, flake-like phyllosilicate grains reorientate during compaction, therefore the highest thermal conductivity values are expected along bedding. Most of the studied samples were oriented so that we measured the thermal conductivity component perpendicular to bedding and thus the lowest values are expected.

\section{Thermal conductivity of quartz-rich rocks}

Quartz is an anisotropic mineral. Its thermal conductivity varies from 6.5 to $11.3 \mathrm{~W} \mathrm{~m}^{-1} \mathrm{~K}^{-1}$ along different optical axes, the average value being $7.7 \mathrm{~W} \mathrm{~m}^{-1} \mathrm{~K}^{-1}$ 
(Horai 1971). The thermal conductivity of quartz derived from our data is about $6.5-7.1 \mathrm{~W} \mathrm{~m}^{-1} \mathrm{~K}^{-1}$, which is lower than the average value given in the literature. Relatively low thermal conductivity values of the siliciclastic rocks cannot be explained with a reorientation of quartz grains during lithification and secondary quartz cementation. The study of thin sections proves that the optical axes of grains are distributed randomly.

We tested thermal conductivity-porosity relationships on samples containing $\mathrm{SiO}_{2}$ more than $95 \%$, but never $100 \%$. However, silica is also a part of other silicate minerals and, consequently, the samples are not pure quartz but may contain up to $15 \%$ other silicates (feldspars, clay minerals, etc.). An addition of $10-15 \%$ clay minerals $\left(\lambda=2 \mathrm{~W} \mathrm{~m}^{-1} \mathrm{~K}^{-1}\right)$ to quartz is sufficient to decrease the matrix thermal conductivity from 7.7 to $6.5 \mathrm{~W} \mathrm{~m}^{-1} \mathrm{~K}^{-1}$, which can explain the results of our observations.

\section{Correlation of the thermal conductivity with porosity-dependent properties}

Most of positive correlations between the thermal conductivity and density, electric resistivity, and seismic velocities can be attributed to the effect of porosity. For example, the data in the thermal conductivity-wet density plot (Fig. 3) are located mostly along a line, which can be explained by a porosityinduced decrease in wet density of quartz-rich rock. The values of wet density and elastic wave velocities at a thermal conductivity of $6.5 \mathrm{~W} \mathrm{~m}^{-1} \mathrm{~K}^{-1}$ almost coincide with those of quartz (Schön 1996). Although there are interactions between the thermal conductivity and the porosity-dependent parameters, due to high variance none of the variables alone can be used to estimate the thermal conductivity indirectly.

\section{CONCLUSIONS}

The bulk thermal conductivity of Cambrian siliciclastic rocks in the Baltic basin is a function of both the mineral composition and the porosity. For the given porosity range $0-30 \%$, the thermal conductivity-porosity relationship can be approximately equally well described by the Wiener mixing model, and the layered and geometric mean models.

Even a small content of rock-forming minerals other than quartz decreases the matrix thermal conductivity. This is also the most probable reason why the thermal conductivity of the studied Cambrian quartz-rich rocks $\left(6.9 \mathrm{~W} \mathrm{~m}^{-1} \mathrm{~K}^{-1}\right)$ is lower than that reported in the literature for pure quartz $\left(7.7 \mathrm{~W} \mathrm{~m}^{-1} \mathrm{~K}^{-1}\right)$.

The thermal conductivity correlates positively with other porosity-dependent parameters. However, because of large variability these parameters cannot be used alone for indirect estimation of the thermal conductivity. 


\section{ACKNOWLEDGEMENTS}

The present study was performed within the framework of the Baltic-German project "Geobaltica", supported by the German Federal Ministry for Education, Science and Technology and by research grant No. 4157 from the Estonian Science Foundation. We are grateful to A. Förster and G. Buntebarth for their constructive reviews.

\section{REFERENCES}

Beck, A. E. 1976. An improved method of computing the thermal conductivity of fluid-filled sedimentary rocks. Geophysics, 41, 133-144.

Beck, J. M. \& Beck, A. E. 1965. Computing thermal conductivity of rocks from chips and conventional specimens. J. Geophys. Res., 70, 5227-5239.

Brigaud, F. \& Vasseur, G. 1989. Mineralogy, porosity and fluid control on thermal conductivity of sedimentary rocks. Geophys. J., 98, 525-542.

Buntebarth, G. \& Schopper, J. R. 1997. Experimental and theoretical investigations on the influence of fluids, solids and interactions between them on thermal properties of porous rocks. J. Phys. Chem. Earth, 23, 1141-1146.

Čermák, V. \& Rybach, L. 1982. Thermal conductivity and specific heat of minerals and rocks. In Landolt-Börnstein: Numerical Data and Functional Relationships in Science and Technology, New Series, Group V (Geophysical and Space Research), Vol. 1a (Physical Properties of Rocks) (Angenheister, G., ed.), pp. 305-343. Springer, Berlin.

Clauser, C. \& Huenges, E. 1995. Thermal conductivity of rocks and minerals. In A Handbook of Physical Constants, Rock Physics and Phase Relations, Vol. 3 (Ahrens, T. J., ed.), pp. 105-125. American Geophysical Union, Washington DC.

Diment, W. H. \& Pratt, H. R. 1988. Thermal Conductivity of Some Rock-Forming Minerals: a Tabulation. USGS Open file report 88-690, U. S. Geol. Survey, Denver Co.

Dreyer, W. 1974. Materialverhalten anisotroper Festkörper: Thermische und elektrische Eigenschaften. Springer, Wien.

Horai, K. 1971. Thermal conductivity of rock forming minerals. J. Geophys. Res., 76, 1278-1308.

Järvimäki, P. 1968. Geotermisistä mittauksista Suomessa [On geothermal measurements in Finland]. Master's thesis, University of Helsinki, Institute of Geophysics (in Finnish).

Kukkonen, I. T. \& Peltoniemi, S. 1998. Relationships between thermal and other petrophysical properties of rocks in Finland. Phys. Chem. Earth, 23, 341-349.

Mokrik, R. 1997. The Palaeohydrogeology of the Baltic Basin. Tartu Univ. Press, Tartu.

Pribnow, D. F. C. \& Sass, J. H. 1995. Determination of thermal conductivity for deep boreholes. J. Geophys. Res., 100(B6), 9981-9994.

Prijatkin, A. A. \& Poljakov, E. E. 1983. Petrophysical Investigations of Rocks. Leningrad University (in Russian).

Schön, J. H. 1996. Physical Properties of Rocks: Fundamentals and Principles of Petrophysics. Handbook of Geophysical Exploration, Vol. 18 (Helbig, K. \& Treitel, S., eds.). Pergamon, Oxford.

Shogenova, A. \& Puura, V. 1997. Petrophysical changes caused by dolomitization and leaching in fracture zones of lower Paleozoic carbonate rocks, North Estonia. In Second Nordic Symposium on Petrophysics, Fractured Reservoirs (Middleton, M. F., ed.). Nordic Petroleum Technology Series: One, 155-185. 


\title{
Balti basseini Kambriumi ladestu terrigeensete kivimite soojusjuhtivus
}

\author{
Argo Jõeleht, Kalle Kirsimäe, Alla Šogenova, Saulius Šliaupa, \\ Ilmo T. Kukkonen, Vita Rastenienè ja Angelīna Zabele
}

Uuriti Eesti, Läti ja Leedu Kambriumi ladestu terrigeensete setendite soojusjuhtivust ja teisi omadusi. Kivimite soojusjuhtivust mõjutab peamiselt nende poorsus, mis uuritud materjali puhul oli vahemikus 0-30\%. Kõige paremini kirjeldavad kvartsirikaste kivimite soojusjuhtivuse ja poorsuse vahelist sõltuvust Wieneri ja "kihiline" segamismudel ning komponentide geomeetriline keskmine. Kivimainese soojusjuhtivus korreleerub positiivselt räni sisaldusega, mis peegeldab kvartsi osakaalu kivimis. Teised peamised kivimit moodustavad mineraalid kahandavad soojusjuhtivust. Terrigeensete setendite soojusjuhtivus korreleerub hästi teiste poorsusest sõltuvate omadustega, nagu märgtiheduse, näiveritakistuse ja elastsete lainete levikukiirustega, kuid ei olene kivimi magnetilistest omadustest.

\section{Теплопроводность кембрийских терригенных пород Балтийского бассейна}

\author{
Арго Йыэлехт, Калле Кирсимяе, Алла Шогенова, Саулиус Шлиаупа, \\ Илмо Т. Кукконен, Вита Растениене и Ангелиина Забеле
}

Изучена теплопроводность кембрийских терригенных пород Эстонии, Латвии и Литвы, а также их химический и минералогический составы и другие петрофизические свойства. Известно, что теплопроводность уменьшается с увеличением пористости пород, а также зависит от их состава. Установлено, что зависимость между теплопроводностью и пористостью в измеренных пределах (0-30\%) лучше всего описывается с помощью смешанных моделей Винера, послойной и геометрической. Теплопроводность терригенных пород хорошо коррелирует с такими зависящими от пористости параметрами, как плотность водонасыщенных пород, кажущееся сопротивление, упругие свойства, однако не связана с магнитными свойствами и диэлектрической проницаемостью. 